\title{
SUSTAINABILITY PRACTICES AND PERFORMANCE IN THE SUGAR AND ETHANOL INDUSTRY
}

\author{
Ademir Antonio Ferreira \\ Doutor em Administração de Empresas \\ Faculdade de Economia, Administração e Contabilidade da Universidade de São Paulo (FEA-USP) \\ São Paulo - São Paulo - Brasil \\ adeafer@gmail.com \\ Joice Chiareto \\ Doutora em Administração \\ Faculdade de Economia, Administração e Contabilidade da Universidade de São Paulo (FEA-USP) \\ São Paulo - São Paulo - Brasil \\ joice.chiareto@usp.br \\ Keysa Manuela Cunha de Mascena \\ Doutora em Administração \\ Universidade de Fortaleza (UNIFOR) \\ Fortaleza - Ceará - Brasil \\ keysamascena@unifor.br
}

\begin{abstract}
This study aimed to identify the sustainability practices of companies in the Brazilian sugarcane industry participating in the Clean Development Mechanism (CDM). We identified sustainability practices in the Global Reporting Initiative (GRI) reports, in the social and environmental dimensions, and we investigated the association with the financial performance. We developed a content analysis of the reports disclosed by 18 groups of companies, controllers of 48 plants of Brazilian sugarcane industry participating in the CDM. The results indicated that the most indicators reported by the plants refer to initiatives and strategies for protection and preservation of the environment. As for the actions developed by the plants with the intention of preservation and environmental protection, we found 25 different actions. The most commonly performed practices are related to the reduction of cane burning and $\mathrm{CO} 2$ emissions; preservation or restoration of the Permanent Preservation Areas (PPAs) and Private Reserve of the Natural Heritage (PRNH) or seedlings cultivation; and electricity generation. We found out, through cluster analysis, that companies that reported more indicators in the social and environmental dimensions also have higher volume of net sales. This study contributes by presenting a performance analysis in sustainability of mills groups finding that there is still opportunity for greater disclosure of the mills sustainability performance, through the disclosure of more comprehensive reports for a more effective communication with stakeholders. This study also contributes to the literature deepening the analysis of a specific context and understanding the different levels of sustainability disclosure.
\end{abstract}

Keywords: Sustainability; Disclosure; Performance; Sugarcane Industry.

\section{PRÁTICAS DE SUSTENTABILIDADE E DESEMPENHO NA INDÚSTRIA DE AÇÚCAR E ETANOL}

\section{RESUMO}

Este estudo teve como objetivo identificar as práticas de sustentabilidade das empresas da indústria brasileira de canade-açúcar que participam do Mecanismo de Desenvolvimento Limpo (MDL). As práticas de sustentabilidade foram identificadas nos relatórios que seguem o padrão da Global Reporting Initiative - GRI, nas dimensões social e ambiental, e a associação com o desempenho financeiro foi investigada. Foi desenvolvida uma análise de conteúdo dos relatórios divulgados por 18 grupos de empresas, controladores de 48 fábricas da indústria de cana-de-açúcar brasileira que participam do MDL. Os resultados indicaram que a maioria dos indicadores reportados refere-se a iniciativas e estratégias de proteção e preservação do meio ambiente. Quanto às ações desenvolvidas com a intenção de preservação e proteção ambiental, foram encontradas 25 diferentes ações. As práticas mais comumente realizadas estão relacionadas à redução da queima de cana e das emissões de $\mathrm{CO} 2$; preservação ou restauração das Áreas de Preservação Permanente (APPs) e da Reserva Particular do Patrimônio Natural (RPPN) ou cultivo de mudas; e geração de eletricidade. Verificou-se, através da análise de clusters, que as empresas que apresentaram mais indicadores nas dimensões social e ambiental também apresentaram maior desempenho financeiro em termos de receitas líquidas. Este estudo contribui ao apresentar uma análise do desempenho em sustentabilidade de grupos de usinas, constatando que ainda há oportunidade de maior divulgação do desempenho em sustentabilidade, através do reporte de relatórios mais abrangentes para uma comunicação mais efetiva com os stakeholders. Este estudo também contribui com a literatura aprofundando a análise de um contexto específico, visando compreender os diferentes níveis de divulgação das práticas de sustentabilidade.

Palavras-chave: Sustentabilidade; Divulgação; Desempenho; Indústria de cana-de-açúcar. 


\section{INTRODUCTION}

High economic growth during the Industrial Revolution brought with it great ecological impacts, such as costs of environmental disaster, air and water pollution, farmable lands degradation, wars, economic and social injustice, human displacement and diseases. Awareness of these costs by business organizations has increased significantly over the last 25 years, especially, among other factors, because of the growth of environmental activism, regulation and democratization (Stead \& Stead, 2000). Sustainability or sustainable development has become important matters within the political and organizational agendas (Moneva, Archel, \& Correa, 2006). In addition, the notion of measurement related to the Triple Bottom Line has become popular among consultants and organizations. The Triple Bottom Line concept assumes that a company success should be measured not only by the traditional financial results, but also for its social / ethical and environmental performance (Norman \& Macdonald, 2004).

A growing number of researches on corporate sustainability have focused on sustainability reports released by the organizations and the organizations' motivations to do and disclosure these reports (Roca \& Searcy, 2012). By doing disclosure of information on corporate social responsibility, economic, social and environmental concerns, companies aim to meet new forms of governance and interests of governments and financial markets in sustainability reports and sustainable development (Gallego, 2006). Taking in consideration all these facts, many researches and consulting companies have started to offer services for organizations that want to measure their results, to audit and prepare reports about its social and environmental performance (Norman \& Macdonald, 2004).

One significant initiative for developing a framework for sustainability reports, aiming at the quality of the companies' socio environmental performance disclosure, was developed by the Global Reporting Initiative (GRI). The GRI is the result of a project of the Coalition for Environmentally Responsible Economies (CERES) with the United Nations Environmental Program that published the first guidelines for sustainability reporting in June 2000 (Moneva et al., 2006). The aim of the GRI guidelines is to "to help reporters prepare sustainability reports that matter, contain valuable information about the organization's most critical sustainability-related issues, and make such sustainability reporting standard practice" (Global Reporting Initiative, 2015, p.3). However, the disclosure of socio-environmental information still has many variations among companies, even adhering to the GRI standard, making relevant an in-depth analysis of corporate disclosure.

These facts are applied to the most diverse types of organizations that use sustainability reporting, among them Brazilian mills of the sugar and ethanol industry. Brazil has an area of 851 million hectares, in which 376 million are farmable lands, of which 5 million have been used for sugarcane crop, representing $1.3 \%$ of the sugarcane production in the available area (Germek et al., 2013). In addition, the job creation by the Brazilian sugarcane industry is very representative, reaching people from different social classes and geographically distributed throughout the country. It is an important part of the agribusiness chain in Brazil, involving companies that produce capital assets, producers of inputs, training facilities and improvement of manpower, research institutions, transportations systems and educational institutions. This industry contribute directly and indirectly to improve people's life quality competently and with social responsibility (Germek et al., 2013).

In this context, this work has as main goal to identify the sustainability practices of the Brazilian sugar and ethanol mills industry that participate in the Clean Development Mechanism (CDM).

In order to guarantee that this objective can be achieved, we defined the three following specific objectives: To measure the results of the mill's practices regarding social and environmental dimensions; to identify the practices undertaken by the mills aiming at 
environmental preservation and protection; to identify the relationship between sustainability practices and financial performance of these organizations.

\section{THEORETICAL FRAMEWORK}

We based this theoretical framework on the Corporate Social Disclosure. In addition, this research focuses on the context of Brazilian Sugar and Ethanol Industry, Clean Energy Production, Clean Development Mechanism and the adoption of GRI to disclosure the social and environmental performance.

\subsection{Disclosure}

When debating about the responsibility of companies towards society we face different opinions from academics, Friedman (1970) argues, "there is one and only one social responsibility of business, to use its resources and engage in activities designed to increase its profits". However, this vision have been facing resistance for some time. Businesses have been pressured to respond to social problems that could be associated with the company activities (Patten, 1991); these problems are usually called externalities. When a company decide to face it's externalities and take action, it needs to find a way to let society know what has been done. The most common way to do that is through disclosure of those practices.

Environmental disclosure is a necessity if companies intend to attend the requested level of accountability (Buhr \& Freedman, 2001). Gray et al. (1996 cited by Buhr \& Freedman, 2001) states that corporate environmental information is crucial, those who control society's natural resources must provide accountability about it, or they could exploit this resources in a way that could damage current and future generations.

Because of its nature, environmental disclosure usually deals with social and economic aspects. For example, excessive emission levels have environmental consequences, but are also harmful for individuals' health, resulting fines and negative corporate image, both that can have economic implications (Buhr \& Freedman, 2001). In response to this kind of demand, several companies started to report information related to their financial performance, management, corporate governance and sustainability record, therefore facilitating the decisions of different stakeholders (García-Sánchez, Rodríguez-Ariza, \& Frías-Aceituno, 2013).

The main research questions related to disclosure are: what companies are reporting? What motivates companies disclosure information related to social and environmental practices? Are social and environmental disclosure linked to economic performance or other factors? (Haniffa \& Cooke, 2005).

As for what is reported by companies, the socio-environmental disclosure still presents many variations regarding the extent and quality of the reported content. Jenkins and Yakovleva (2006) consider different levels of maturity and classification of sustainability reports, classifying groups of companies as mature, adolescent and child. The mature group, according to this classification, uses the GRI standards and audit procedures of the reports (Jenkins \& Yakovleva, 2006). Standardized reports were developed to help companies to report their social and environmental practices; one of them is the GRI. This report have been successful institutionalized by many measures, but it is still restricted mainly to multinational companies, financial institutions, international business management consultancies and accountancies, what is a much narrower extent than the initial vision for GRI (Brown et al., 2009).

Regarding the motivation to disclosure, Cormier and Magnan (2015) emphasizes that companies may consider both the environmental disclosure to increase economic and market performance and with the aim of legitimizing the organization practices for its stakeholders. In addition, studies can analyze different contexts and countries to understand disclosure.

Revista de Gestão Social e Ambiental - RGSA, São Paulo, v. 13, n. 1, p. 57-75, jan./abr. 2019. 
Third, the link between social and environmental disclosure with performance was studied by some researchers but remains a subject to be analyzed in different contexts. Some studies found a positive relationship between disclosure and financial performance. Chen, Feldmann, and Tang (2015) have studied this relationship by measuring disclosure through GRI reports. They find an association between some GRI indicators and financial performance in manufacturing companies. The indicators most associated with financial performance were human rights, society and product responsibility. Qiu, Shaukat, and Tharyan (2016) find a relationship between high levels of social disclosure and the market performance. They point out, however, that it is high profitability that leads to a higher disclosure, ie companies with higher economic returns tend to increase the extent of social disclosure. Platonova, Asutay, Dixon, and Mohammad (2018) also found a positive relationship when studying Islamic banks and, unlike Chen et al. (2015), this positive relation is evidenced when analyzing the indicators together. In another context, Oyewumi, Ogunmeru, and Oboh (2018) studied banks in Nigeria and found a positive relationship of social disclosure with financial performance. Negative relations were also found in the literature, both in the international context (Mathuva and Kiweu 2016), and in the Brazilian context (Holanda, Almada, De Luca, \& Gallon, 2011; Viviani, Moura, Macêdo, \& Silva, 2014).

\subsection{Brazilian Sugar and Ethanol Industry}

The activities of the Brazilian sugar and ethanol industry have some centuries of history, and this industry rose to prominence at the peak of the sugarcane cycle in colonial Brazil in the XVI century (Pacheco \& Hoff, 2013). Afterwards there was a decline in the importance of this industry to the economy. Its activities regained relevance only in the late twentieth century and the main cause of this return was the 1970 oil crisis.

At that time the oil main producing countries of the Middle East, such as Saudi Arabia, Iran, Iraq and Kuwait begin to regulate the amount of exported oil. Moreover, the most critical time of this process occurred in 1973, when, in retaliation against the United States and some European countries' position in the War of Yom Kippur (Day of Atonement), those countries established an embargo on the oil export to the USA (IPEA, 2010). That shock was so great that the barrel price rose about $400 \%$ in three months, going from US\$2.90 in October 1973 to US\$ 11.65 in January 1974 (IPEA, 2010).

Seeking to react to these events, in the 1970s and 1980s some macroeconomic policies were implemented in Brazil aiming to create programs for technological innovation and also the mandatory use of ethanol as an automotive fuel, such as the National Alcohol Program PROÁLCOOL (Conab, 2010; Pacheco \& Hoff, 2013). These actions helped the evolution of production techniques and use of new technologies in the industry and still in the 1980s the ethanol production in industrial scales was started (Pacheco \& Hoff, 2013).

A large domestic market was created for ethanol and Brazil ended up by developing a model of mixed industry, unique in the world, for that time, by allocating a portion of the sugar cane juice to produce sugar and another portion for ethanol manufacturing (Conab, 2010). However the government incentives for the sugarcane industry began to decline in the second half of the 1980s, with the extinction of the IAA (Sugar and Alcohol Institute) accomplished in 1991 (Barros, 1996).

Occurrences, such as the producer prices set below the production costs, reduction of domestic consumption, equivalence between ethanol and gasoline prices, increase of uncertainties in the industry, lack of investment for the research about sugarcane and lack of incentive to consumption of renewable fuels, led to a large decrease in the industry's strength in the 1990s (Barros, 1996). The industry started to benefit once again from the technological and institutional evolution only in the 2000s (Pacheco \& Hoff, 2013), among other reasons, because of the concern about increasing air pollution and the signing of the Kyoto Protocol in 1998.

Brazil is currently the world's largest sugarcane producer, having reached a record production of 620 million tons of sugarcane in the 2010-2011 harvest; this volume generated almost

Revista de Gestão Social e Ambiental - RGSA, São Paulo, v. 13, n. 1, p. 57-75, jan./abr. 2019. 
38 million tons of sugar and more than 27 billion liters of ethanol (Nyko et al., 2013). The Brazilian biofuel industry is the most developed and integrated in the world and the Brazilian liquid biofuels are known worldwide. Bioethanol, which comes from sugar cane, is especially important, among other reasons, because, from a technical and economic point of view, it is easier and much cheaper to produce bioethanol from sugar cane than from corn such as in the US. These advantages sugarcane ethanol is actually an opportunity for the producer countries to diversify the sugar industry through the introduction of new by-products of sugarcane, such as larger use of bioethanol as fuel and development of new derived products (Pippo \& Luengo, 2013).

According to Pacheco and Hoff (2013), the new laws governing the industry and the pressures for use of cleaner forms of energy led to many advances in the industry, such as: a) Gains in productivity in sugarcane, ethanol and sugar production; b) Expansion of the demand for fuel and sugar because of the advent of automotive engines type flex and the change in the food consumption profile in many parts of the world; c) Evolution of the processes involved in the production chain, contributing to a more efficient and cleaner production pattern, such as the reuse of by-products within the own chain, reducing environmental externalities; and d) Diversification of the products derived from sugar and ethanol production chain, with more sophisticated products such as the cellulosic ethanol, yeast, polymers, solvents and carbon credits - allowed thanks to the institutional evolution in the field of environmental protection.

The Brazilian sugar and ethanol industry is also a great field for clean energy production for the mills themselves or even for selling, mostly using sugarcane bagasse (Pacheco \& Hoff, 2013).

\subsection{Brazilian Sugar and Ethanol Industry and the Clean Energy Production}

The national average production is of 75 tons of sugarcane per hectare, which provides 8.5 tons of sugar or 5,400 liters of ethanol and 19.5 tons of bagasse with $50 \%$ of humidity. The sugarcane's burning activities, the bagasse's burning and the produced alcohol burning, regarding to one ton of cane produce 13.4 tons of $\mathrm{CO}_{2}$ and absorbs 0.9 tons of oxygen. However, the growing of the same ton of cane removes from the atmosphere 109 tons of $\mathrm{CO}_{2}$ and returns 70 tons of oxygen (Germek et al., 2013). This cycle removes about eight times the $\mathrm{CO}_{2}$ it produces, while gasoline releases into the atmosphere three tons of $\mathrm{CO}_{2}$ per ton of fuel without any environmental compensation besides producing more aggressive pollutants (Eston, 1990 cited Germek et al., 2013).

Another relevant issue is the interaction of mills with the environment regarding the production of electric energy using sugarcane bagasse. First, there is the potential for selfsufficiency of the industry's industrial units (Pacheco \& Hoff, 2013). In other words, initially it is already possible for the mills to produce the whole amount of electricity that will be consumed in their industrial processes, without the need to purchase electricity from the public power grid. However, beyond that there is the possibility of the mills to co-generate electric power, working in together with the national distribution system (Pacheco \& Hoff, 2013). In the future, sugar and ethanol mills can become islands of alternative energy production through using the total sugarcane and its by-products (Germek et al., 2013). For example, use of sugar cane bagasse for electric power generation can make it a product as profitable as sugar and ethanol (Conab, 2010).

In a study published in 2013, it was estimated the potential values that the sugar industry could offer with its biomass to generate electricity (Bioelectricity). The results showed that the potential mills in Brazil could produce between $45-58 \%$ of the Itaipu Hydroelectric Power Plant potential (Germek et al., 2013). But the process to reach that potential are not something as simple, even the clean production practices already used by the mills currently do not depend exclusively from them. Many of these cleaner production practices are possible thanks to a particular technology package external to the sector. Therefore, the innovation efforts carried out in the sectors of machinery, industrial equipment and agricultural implements strikes directly on the environmental results of the sugar and ethanol industry (Pacheco \& Hoff, 2013).

Revista de Gestão Social e Ambiental - RGSA, São Paulo, v. 13, n. 1, p. 57-75, jan./abr. 2019. 


\subsection{Clean Development Mechanism (CDM)}

The establishment of the Kyoto Protocol, signed in 1997, sought the commitment of the signatory countries to reduce the emission of greenhouse gases (GHG) in the atmosphere (Brazil, 2014). The average reduction target was of 5.2\% between 2008 and 2012, based on the 1990's emissions. The latest text of the Protocol however foresees cuts of $25 \%$ to $40 \%$ in the developed countries emissions by 2020, based on the 1990's levels (Brazil, 2014).

Among the many commitments to be undertaken by the signatory countries the ones that most stand out were: a) Increase of energy efficiency in relevant industries of the economy; b) Research, development and increase of renewable energy use, use of Carbon dioxide $\left(\mathrm{CO}_{2}\right)$ capture and sequestration (CCS) technologies and use of environmentally safe technologies; c) Conducting of promotion policies and of measures that limit or reduce the emissions of greenhouse gases; d) Actions to limit and / or reduce emissions of greenhouse gases in transportation industry (Brazil, 1997).

However, the developed countries have had some difficulties in achieving the set targets, mainly because of the high cost to carry out the reductions in their countries. For this reason there were created alternative ways to allow to able countries to fulfill their part in the agreement. It was established three additional mechanisms to complement measures to reduce the emissions of greenhouse gases by the signatory countries: the Clean Development Mechanism - CDM; the Joint Implementation; and the Emissions Trading - ET (Frondizi, 2009). The Clean Development Mechanism allows the developing countries active participation in the Kyoto Protocol implementation of the UNFCCC (United Nations Framework Convention on Climate Change) (Silveira, 2005).

The Climate Change Department of the Ministry of Environment (MMA) explains that the CDM allows the developing countries to benefit from the activities of reducing the greenhouse gases emissions, and subsequently sale the Certified Emissions Reductions (CERs) (Brazil, 2014). These credits (CERs) can be sold or traded with developed countries, that have the obligation to reduce the greenhouse gases emissions, but whose emissions are still above the limits agreed under the Kyoto Protocol. The sale of CERs, also known as carbon finance, carbon credits or emission reduction units, are generally carried out through the support to projects aiming at the GHG emission reductions, where the country financing the project have rights over the credits generated by the projects it supports. The CDM serves as a tangible mean to help developing countries to use the resulting CERs to achieve their reduction goals (Lloyd \& Subbarao, 2009).

The contributions of CDM project activities for the sustainable development are evaluated by several criteria such as: Contribution to local environmental sustainability; Contribution to the development of working conditions and job creation; Contribution to income distribution; Contribution to technological empowerment and development; Contribution to regional integration and to the sectorial relationships (Brazil, 2014).

The CDM also has a series of requirements to be developed, the emissions reductions must be measurable and quantifiable, as well to provide an improvement compared to a pre-defined baseline. The baseline is the expected trajectory of the emissions in the absence of the project. The project's contribution to reduce the emissions implies the issue of CERs, which can be traded internationally after the project proper validation and verification of its achieved emissions reductions (Silveira, 2005). The project's activities need to show real, measurable and long-term benefits and demonstrate the emissions reductions of greenhouse gases or the increase in the $\mathrm{CO}_{2}$ removal from the atmosphere (Frondizi, 2009).

The involvement of the private sector has been very important for the CDM development such as in the replacement of fossil energy by other renewable sources, rationalization of energy use, forestation and reforestation activities (Frondizi, 2009). In this context, bioenergy, such as that produced by the sugar and ethanol mills in Brazil, stands out as an attractive option, capable of

Revista de Gestão Social e Ambiental - RGSA, São Paulo, v. 13, n. 1, p. 57-75, jan./abr. 2019. 
meeting the socio-economic requirements imposed on CDM projects and contribute to climate change mitigation (Silveira, 2005).

Considering the importance of mechanisms like CDM, in the company level, means for the companies to disclosure their actions related to sustainability should also be considered, one of the is the Global Reporting Initiative (GRI).

\subsection{Global Reporting Initiative (GRI)}

The Global Reporting Initiative is a not-for-profit organization headquartered in Amsterdam, the Netherlands, though it was founded in Boston in 1997. Currently it has seven focal sites located in the continents of America, Europe, Asia, Africa and Oceania. The GRI develops disclosure standards of social and environmental performance and its mission is to empower decision makers everywhere, through our sustainability standards and multi-stakeholder network, to take steps towards a more sustainable and global economy (Global Reporting Initiative, 2015). Operating on an international level, the GRI is considered a widely accepted initiative, also being the most important in terms of social and environmental disclosure (Waddock, Bodwell, \& Graves, 2002). In the Brazilian studies, many researches find the GRI framework as the most adopted standard for sustainability reports (e.g. Silveira, Alberton \& Vicente, 2017).

The GRI has developed a framework for sustainability reports that can be adopted by organizations of different sizes, industries and countries. The first version of the Framework for GRI Sustainability Reporting was launched in 2000 and the last version, fourth, in 2013 (Global Reporting Initiative, 2015).

Its founders aimed that the GRI would become a platform for a widely participative dialogue about what constitutes the organizations' sustainability performance. The founders' strategy was: a) To mobilize a broad coalition of participants, who had not previously thought of themselves as members of the sustainability movement, and engage them in a discussion around a set of rules, practices and guidelines of the GRI reports; b) To create a mechanism to keep the discussion working in the future and build a sense of shared ownership of the new rules and practices; and c) To create an organization which would serve as the guidelines and the GRI evolutionary process manager (Brown, Jong, \& Levy, 2009).

The GRI framework in its latest version consists of general and specific standard content. The standard general contents are: Strategy and Analysis; Organizational Profile; Material Aspects Identified and Limits; Stakeholder Engagement; Report Profile; Governance; Ethics and Integrity. The standard specific contents are: Information on the Management Approach; and Indicators. GRI has more than seventy indicators, which are organized into economic, social and environmental dimensions (Global Reporting Initiative, 2015).

Although the framework is very detailed, its adoption is voluntary. So when preparing its sustainability report, each company decides which indicators it will report. The GRI framework provides guidance on how organizations can disclose their sustainability performance with directives, protocols, industry supplements, a detailed list of performance metrics and other items (Toppinen Li, Tuppura, \& Xiong, 2012). The GRI indicators are a guide for the disclosure of sustainability, but companies may not report them in the same way. Therefore, there is room for research on the quality and comprehensiveness of the disclosure of sustainability indicators (Tannuri \& Van Bellen, 2014).

\section{METHODS}

This work was classified as a descriptive and exploratory research (Cervo \& Bervian, 1996). The research method was the documental research, as a main source of data we used the GRI reports released by mills groups in Brazilian sugar and ethanol industry that participate in the Clean

Revista de Gestão Social e Ambiental - RGSA, São Paulo, v. 13, n. 1, p. 57-75, jan./abr. 2019. 
Sustainability practices and performance in the sugar and etanol industry

Development Mechanism. In order to complement the financial information, we also consulted the selected groups' websites.

\subsection{Data collection and analysis}

First, in order to identify the practices developed by the mills that aimed environmental preservation and protection we used the technique of content analysis. Generally, the content analysis is a set of techniques which seeks to describe, through systematic procedures, the content of the messages and draw up indicators (quantitative or not), so that it is possible to carry out inferences on the data collected (Bardin, 2011).

In Brazil there are more than 400 sugarcane mills (Novacana, 2019), this research was limited to companies with projects related do the CMD from UNFCCC (United Nations Framework Convention on Climate Change), and by the availability of reports. In the pre-analysis phase, we conducted a brief reading of the 25 available reports from the year of 2014. After this initial reading, we decided to withdraw seven reports from the analysis.

From the initial set, 8 reports were of different mills, but they belonged to the same group of companies, this happened with the reports of the groups: Louis Dreyfus Group (Usina Vale do Rosário, Usina Santa Eliza 2, Usina MB and Usina Cresciumal 2), Raizen Group (Usina Tarumã and Usina Maracai) and Renuka Brazil Group (Usina Mahandu and Usina Revalti). All information disclosed in each one of these reports referred to all mills of the group, so all the information was repeated. For this reason, only one report from each of these groups was used, resulting in the exclusion of five of reports, keeping only one report for each group.

It was also excluded the report of the Usina Bionergia (Lucélia), whose corporate name is Bioenergia do Brasil S.A., because of the fact that it brought only the information related to one of the GRI indicators and did not refer to the mill itself, but apparently to a company from another industry.

The last report we excluded was one of the Raizen Group reports relating to 23 mills. Considering the large number of mills included in the Raizen Group report it could be considered an outlier, being so we decided to exclude this report from the research. The Raizen Group's report concerning Usina Tarumã 2 was held because it was related to only this mill individually. Therefore, for the results analysis we used GRI reports of 18 groups of companies, controllers of 48 mills.

In addition to the data obtained in the sustainability reports, we also sought to define a financial performance variable of the mills. The financial performance variable selected was the net revenue, as it was available to a larger number of companies. For those companies that did not provide the net revenue in the sustainability report, we obtained the information on their websites and on the website of the Best and Largest of Exame Magazine (Exame, 2014). Net revenue was used for data availability and also for being a variable in the literature that is associated with sustainability performance (Székely, \& Knirsch, 2005).

Another data analysis technique used was the cluster analysis, a technique that aims at grouping together groups of mills, homogeneous within the cluster and at the same time that the formed clusters are heterogeneous with each other. The companies were grouped together according to the environmental and social performance, achieved through the frequency of indicators responded in each of these two dimensions.

After the grouping, we verified the difference of mean among the groups with the analysis of variance technique (ANOVA). The difference of mean covered not only the frequency of indicators for the two dimensions but also the financial performance, obtained through the net revenues, in order to check whether there is association among variables. The analysis was performed with the support of the SPSS software. 


\section{RESULTS AND DISCUSSION}

\subsection{Analysis of information disclosure in the environmental dimension}

In an initial analysis of the environmental and social dimensions of the GRI, the information was organized according to the disclosure or not of the indicators by the groups of companies. To classify if one indicator were reported or not, we compared the indicator description on the G4 Guidelines for Sustainability Reporting (Global Reporting Initiative, 2015) and the information disclosed by the group. It was regarded as presented if the information disclosed by the group met, at least partially, the indicator description requirements. From a total of 27 possible indicators and 18 company groups, each group presented on average 4.33 indicators, with a standard deviation of 4.25. Only about $15 \%$ ( 4 indicators) had information presented by 10 or more companies. The indicators most frequently presented can be seen in Table 1.

Table 1.

Indicators most frequently reported - environmental

\begin{tabular}{|l|c|}
\hline \multicolumn{1}{|c|}{ Indicator and Description } & Frequency \\
\hline $\begin{array}{l}\text { EN6 - Calculate or estimate the energy saved by initiatives to reduce energy use and increase } \\
\text { energy efficiency. }\end{array}$ & 10 \\
\hline $\begin{array}{l}\text { EN12 - Identify significant positive and negative impacts on biodiversity associated with } \\
\text { activities, products, and services of the organization, including both direct impacts as well as } \\
\text { indirect impacts (such as in the supply chain). }\end{array}$ & 12 \\
\hline $\begin{array}{l}\text { EN13 - This Indicator refers to areas in which remediation has been completed or the area is } \\
\text { actively protected. Areas in which operations are still active can be counted if they conform to } \\
\text { the definitions of 'restored' or 'protected'. }\end{array}$ & 14 \\
\hline $\begin{array}{l}\text { EN14 - Identify the location of habitats affected by the operations of the organization that } \\
\text { include species on the International Union for Conservation of Nature (IUCN), Red List of } \\
\text { Threatened Species, and on national or regional conservation lists. }\end{array}$ & 12 \\
\hline $\begin{array}{l}\text { EN18 - Select an appropriate ratio denominator to represent per unit output, activity, or any } \\
\text { other organization specific metric. }\end{array}$ & 13 \\
\hline
\end{tabular}

It is possible to notice that all indicators of higher frequency are related to the organizations initiatives and strategies for environmental protection and preservation, these indicators do not present exactly the quantitative results. Therefore, it becomes difficult to measure the real impact of these initiatives on the organizations sustainability.

Even the EN13 indicator (protected or restored Habitats) was presented by 8 of the 14 organizations in the form of initiatives, strategies or programs for preservation rather than hectares of protected or restored land. Despite this problem, the accomplishment of activities related to the environment protection and preservation are consistent with the participation of these organizations in the CDM, as a mean to obtain the Certified Emission Reductions (CERs). In the other extreme, $56 \%$ (15 other indicators) were informed only by three or fewer groups, and out of these, nine indicators were presented only by one or no group.

\subsection{Analysis of information disclosure in the social dimension}

From 14 indicators found in the reports of 18 groups of companies, 10 or more groups of companies reported about $28.57 \%$ (4 indicators). The same amount $28.57 \%$ (4 indicators) was reported by 2 or fewer groups. From a total of 14 possible indicators and 18 company groups, each indicator was reported, on average, by 4.5 company groups, with a standard deviation of 2.57 . The indicators most frequently reported can be seen in Table 2 . 
Table 2.

Indicators most frequently reported - social

\begin{tabular}{|l|c|}
\hline Indicator and Description & Frequency \\
\hline $\begin{array}{l}\text { LA2 - Total number of employees and the respective turnover rate by age bracket, gender and } \\
\text { region. }\end{array}$ & 13 \\
\hline $\begin{array}{l}\text { LA8 - Programs in education courses, training, counseling, prevention and risk control, now } \\
\text { underway, to ensure assistance to the workers and to their families or community members } \\
\text { affected by serious diseases. }\end{array}$ & 13 \\
\hline $\begin{array}{l}\text { LA11 - Programs for competences management and ongoing learning that support the continued } \\
\text { employability of the employees and for the career management }\end{array}$ & 11 \\
\hline $\begin{array}{l}\text { LA3 - Benefits ensured to full-time employees that is not granted to temporary or part-time } \\
\text { employees. }\end{array}$ & 10 \\
\hline
\end{tabular}

It is possible to notice that two of the most frequent indicators are related to the organization's programs, in this case, programs related to human resource management. The LA2 indicator was presented by 13 groups, however, often incomplete, and 9 companies only reported the total number of employees. Because of the lack of quantitative results, it is difficult to measure the real impact of these initiatives on the organization's resources.

\subsection{Analysis of information disclosure - social and environmental dimension}

When carrying out the information disclosure crosschecking of social and environmental dimensions we established a ranking with the companies with higher total frequency of indicators report. The crosschecking of the information report by group of companies can be seen in Table 3 .

Table 3.

The information report crosschecking- social and environmental

\begin{tabular}{|c|c|c|c|}
\hline Company & Environmental & Social & Total \\
\hline Grupo Louis Dreyfus Commodities & 15 & 8 & 23 \\
\hline Usina Alto Alegre S/A & 11 & 8 & 19 \\
\hline Grupo Zilor & 10 & 8 & 18 \\
\hline Grupo Bunge & 8 & 7 & 15 \\
\hline Grupo Colombo 2 & 7 & 6 & 13 \\
\hline Grupo Raízen & 4 & 9 & 13 \\
\hline Usina Jalles Machado & 6 & 5 & 11 \\
\hline Usina Alta Mogiana & 7 & 3 & 10 \\
\hline Grupo Renuka Brasil & 6 & 4 & 10 \\
\hline Grupo Balbo & 6 & 3 & 9 \\
\hline Usina Caetes & 4 & 5 & 9 \\
\hline Usina Santa Adelia & 7 & 2 & 9 \\
\hline Grupo Tercio Wanderley & 6 & 2 & 8 \\
\hline Grupo Tereos & 5 & 3 & 8 \\
\hline Grupo Tonon Bioernegia S S/A & 5 & 2 & 7 \\
\hline Usina Itamarati & 4 & 2 & 6 \\
\hline Grupo Pedra Agroindustrial S/A & 2 & 3 & 5 \\
\hline Usina Cerradinho & 4 & 1 & 5 \\
\hline
\end{tabular}

The average of total of indicators reported was of 11 indicators per group, with a standard deviation of 5.01. Regarding the report of environmental and social indicators combined, the ranking shows the group with the highest disclosure index the Louis Dreyfus Commodities Group with disclosure of 23 indicators. The second group with greater disclosure is the Usina Alto Alegre Group S/A, with 19 indicators. However 9 (50\%) of the present studied groups present which may be considered low disclosure, 10 or fewer indicators.

These highly heterogeneous and dispersed results are consistent with results from other researches about disclosure of sustainability reporting. Roca and Searcy (2012) studied a total of 94 
Canadian corporate sustainability reports, the authors found in these reports 585 different indicators, and 324 indicators were used only once, 91 were highlighted by two corporations and 40 were mentioned by three corporations. Looking at the other extreme, very few indicators were highlighted in most reports: 10 indicators were highlighted in more than 20 reports, but only three of them were highlighted in up to 40 reports (Roca \& Searcy, 2012).

These results may indicate that the company, even in developed countries, operates similarly in the disclosure of their sustainability reports.

The average of total of indicators reported was of 11 indicators per group, with a standard deviation of 5.01. Regarding the report of environmental and social indicators combined, the ranking shows the group with the highest disclosure index the Louis Dreyfus Commodities Group with disclosure of 23 indicators. The second group with greater disclosure is the Usina Alto Alegre Group S/A, with 19 indicators. However $9(50 \%)$ of the present studied groups present which may be considered low disclosure, 10 or fewer indicators.

These highly heterogeneous and dispersed results are consistent with results from other researches about disclosure of sustainability reporting. Roca and Searcy (2012) studied a total of 94 Canadian corporate sustainability reports, the authors found in these reports 585 different indicators, and 324 indicators were used only once, 91 were highlighted by two corporations and 40 were mentioned by three corporations. Looking at the other extreme, very few indicators were highlighted in most reports: 10 indicators were highlighted in more than 20 reports, but only three of them were highlighted in up to 40 reports (Roca \& Searcy, 2012).

These results may indicate that the company, even in developed countries, operates similarly in the disclosure of their sustainability reports.

\section{Table 4.}

Indicators related to the practices aiming environmental preservation and protection

\begin{tabular}{|l|c|c|}
\hline \multicolumn{1}{|c|}{ Indicator } & Companies & \% \\
\hline $\begin{array}{l}\text { EN6 - Initiatives to supply products and services based on the energy efficiency or on } \\
\text { the renewable energy sources, and reductions in the energy consumption as a result } \\
\text { of these initiatives. }\end{array}$ & 10 & $52,63 \%$ \\
\hline EN7 - Initiatives to reduce the indirect energy consumption and the achieved savings & 8 & $42,11 \%$ \\
\hline EN10 - Total percentage and total volume of recycled and reused water. & 3 & $15,79 \%$ \\
\hline EN13 - Habitats protected or restored. & 14 & $73,68 \%$ \\
\hline $\begin{array}{l}\text { EN14 - Strategies and programs, current and future, of management of impacts on } \\
\text { biodiversity. }\end{array}$ & 12 & $63,16 \%$ \\
\hline $\begin{array}{l}\text { EN18 - Initiatives to reduce emissions of greenhouse gases as well as the achieved } \\
\text { reductions. }\end{array}$ & 13 & $68,42 \%$ \\
\hline $\begin{array}{l}\text { EN25 - Identity, dimension, statute of protection and value for the biodiversity of the } \\
\text { hydric resources and related habitats, significantly affected by water discharges and } \\
\text { surface runoff. Aspect: Products and Services. }\end{array}$ & 1 & $5,26 \%$ \\
\hline $\begin{array}{l}\text { EN26 - Initiatives to mitigate the environmental impacts of products and services and } \\
\text { degree of reduction of the impact. }\end{array}$ & 1 & $5,26 \%$ \\
\hline
\end{tabular}

Within the selected set of 18 groups of companies, there was a range of actions related to the intention of environmental preservation and protection. In order to facilitate the analysis, we surveyed the practices carried out by at least two groups of companies, which has resulted in 25 different practices. The average of practices was of 6.78 practices per group with a standard deviation of 3.19. The detailing of all practices can be seen in Table 5.

\section{Table 5.}

Practices developed by the groups

\begin{tabular}{|l|c|}
\hline Practices developed by the mills aiming environmental preservation and protection & Groups \\
\hline It is self-sufficient in electric energy production & 6 \\
\hline It exports electric energy & 6 \\
\hline
\end{tabular}


Sustainability practices and performance in the sugar and etanol industry

\begin{tabular}{|l|c|} 
It generates electricity for own use & 11 \\
\hline It carries out actions to reduce or eliminate the burning of sugarcane and CO2 emission & 12 \\
\hline $\begin{array}{l}\text { It has programs that give priority to product quality and efficiency, as well as to reduction } \\
\text { environmental impacts }\end{array}$ & 5 \\
\hline It declare to follow the environmental legislation & 3 \\
\hline It has programs for sustainable development & 4 \\
\hline It invests in reduction of energy consumption & 3 \\
\hline It invests in increase of productivity & 2 \\
\hline It invests in increase of energy production & 3 \\
\hline It declare working with Carbon Credit (CDM) & 4 \\
\hline It carries out recycling and reuse of water & 4 \\
\hline It has partnerships for environmental protection and / or awareness & 7 \\
\hline It carries out preservation or restoration of Permanent Preservation Areas (PPAs) and Private \\
Reserve of the Natural Heritage (PRNH) or seedlings cultivation. & 12 \\
\hline It makes identification of endangered species & 4 \\
\hline It makes biological pest control & 2 \\
\hline It is involved with other programs, actions and certifications for environmental preservation & 8 \\
\hline It carries out the restocking of rivers & 2 \\
\hline It uses filter cake in crop fertilization & 4 \\
\hline It supports scientific researches & 3 \\
\hline It features the Agro Environmental Protocol & 6 \\
\hline It carries out environmental monitoring & 2 \\
\hline It features ISO 14001 Certification & 4 \\
\hline It features Renewable Fuel Standard 2 & 2 \\
\hline It features ISO 9001 & 3 \\
\hline
\end{tabular}

We noticed a wide dispersion between the practices accomplished by the companies. The Usina Cerradinho, for example, discloses only one a practice aiming environmental preservation and protection. But the Louis Dreyfus Commodities Group discloses 12 of 25 possible practices listed in this work. On average each practice is carried out by 4.88 groups, with a standard deviation of 3.03. The most common practices disclosed by the groups are: (1) Reduce or eliminate the burning of sugarcane and CO2 emissions; (2) Preservation or restoration of Permanent Preservation Areas (PPAs) and RPPN (Private Reserve of Natural Heritage) or seedlings cultivation; and (3) Electricity power generation for its own use.

Two practices that are worth mentioning are the reduction or elimination of sugarcane burning and $\mathrm{CO} 2$ emissions and the preservation or restoration of Permanent Preservation Areas (PPAs) and PRNP or seedlings cultivation. For the first practice, considering the production cycle of a mill, the smaller the amount of sugar burnt, the lower the amount of $\mathrm{CO} 2$ released into the atmosphere. Reducing emissions also implies directly into better results for the CDM. The power generation is something very characteristic of the sugar cane plants. Energy sources used by the mills are something promising for the future. These three practices most widespread by the organizations are strongly associated with the participation of the private industry in the CDM, mostly in the substitution of fossil energy by others of renewable sources, rationalization of energy use, forestation and reforestation activities (Frondizi, 2009).

\subsection{Sustainability practices and the financial performance}

The third objective of the research is to identify the relationship between sustainability practices with the financial performance of these organizations. Given the sample size, we used the exploratory technique of clusters analysis to identify clusters of social and environmental performance and to check if there is any association between socio-environmental performance and financial performance through the mean difference among the clusters, employing the analysis of variance technique - ANOVA. 
First using hierarchical cluster analysis, shown in the dendrogram, we to analyze three clusters, grouping the companies according to the total indicators of the social and environmental dimension, shown in Figure 1.

Figure 1. Cluster Analysis Dendrogram

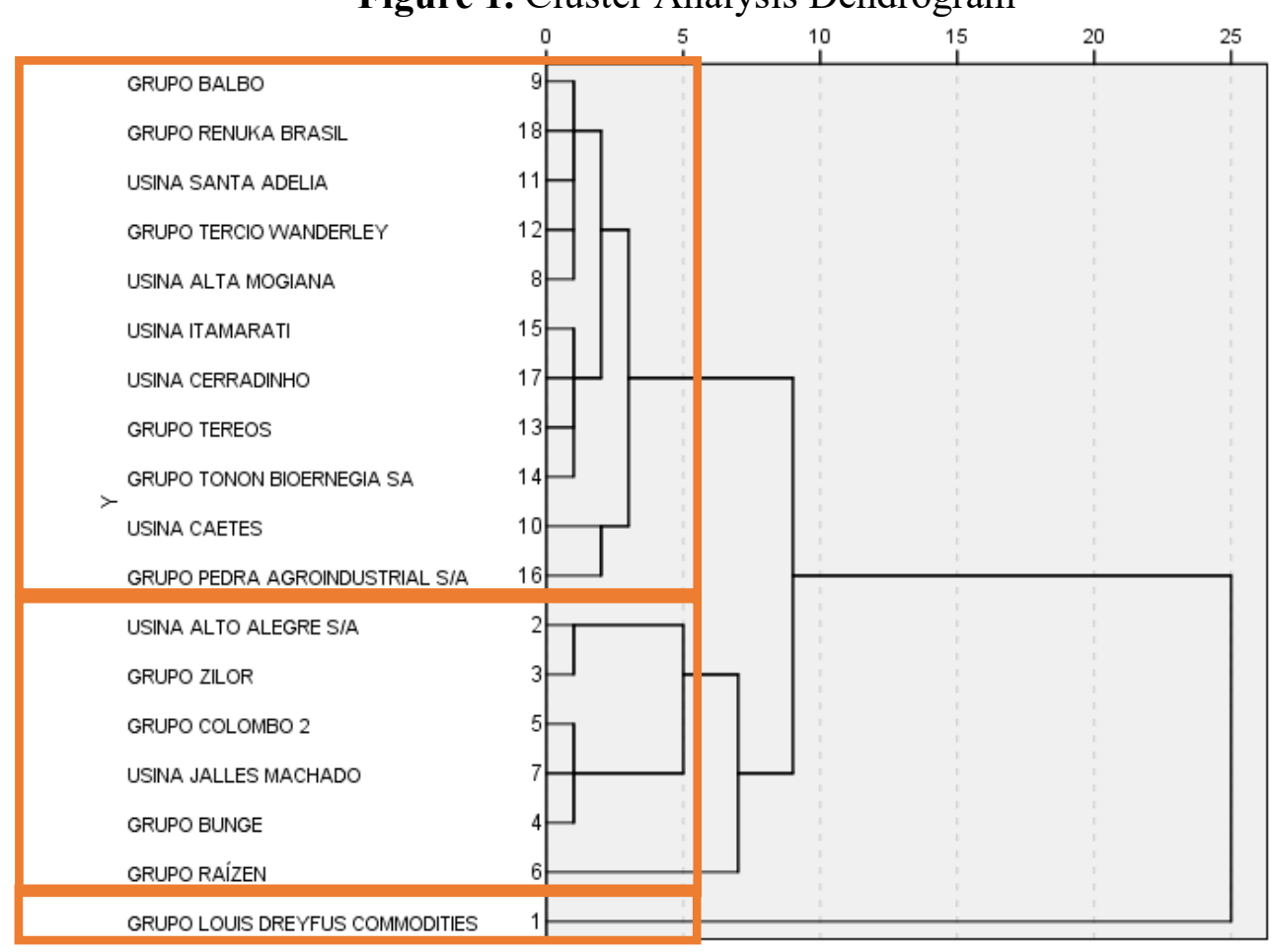

The first cluster contains only one company, the second contains six companies and the third, eleven companies. It was applied the ANOVA technique, to investigate the differences of the financial variable mean, as well as of the environmental and social variables along the groups. The results reveal that there are differences of mean between, at least, two clusters for the three variables, at the level of significance of 5\%. The results are shown in Table 6.

Table 6.

ANOVA Results

\begin{tabular}{l|l|r|r|r|r|r}
\hline \multicolumn{2}{c|}{} & Sum of squares & \multicolumn{1}{c}{$\begin{array}{c}\text { Degrees } \\
\text { of } \\
\text { freedom }\end{array}$} & Mean square & F & Sig. \\
\hline \multirow{3}{*}{ Environmental } & Between groups & 102,258 & 2 & 51,129 & 13,636 & 0,000 \\
\cline { 2 - 8 } & Within groups & 56,242 & 15 & 3,749 & & \\
\cline { 2 - 8 } & Total & 158,500 & 17 & & & \\
\hline \multirow{3}{*}{ Focial } & Between groups & 89,485 & 2 & 44,742 & 29,161 & 0,000 \\
\cline { 2 - 8 } & Within groups & 23,015 & 15 & 1,534 & & \\
\cline { 2 - 8 } & Total & 112,500 & 17 & & & 0,018 \\
\hline
\end{tabular}

The differences of mean can be observed through the clusters descriptive statistics and through the graphs, as shown in Table 7 and Figure 2. It is noteworthy that the environmental and social variables refer to the number of reported indicators and the variable financial performance refers to net revenues, and therefore are numbers with more digits. Because there is no comparison among the variables, only among clusters, there was no need to standardize them. 
Sustainability practices and performance in the sugar and etanol industry

Table 7.

Descriptive Statistics of the clusters

\begin{tabular}{|c|c|c|c|c|c|c|c|}
\hline & & $\mathrm{N}$ & Mean & $\begin{array}{l}\text { Standard } \\
\text { deviation }\end{array}$ & Standard Error & Minimum & Maximum \\
\hline \multirow{4}{*}{ 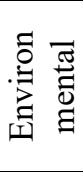 } & Cluster 1 & 1 & 15,0000 & & & 15,00 & 15,00 \\
\hline & Cluster2 & 6 & 7,6667 & 2,58199 & 1,05409 & 4,00 & 11,00 \\
\hline & Cluster3 & 11 & 5,0909 & 1,51357 & 0,45636 & 2,00 & 7,00 \\
\hline & Total & 18 & 6,5000 & 3,05345 & 0,71970 & 2,00 & 15,00 \\
\hline \multirow{4}{*}{$\begin{array}{l}\bar{\pi} \\
\text {. } \\
0 \\
\text { n }\end{array}$} & Cluster 1 & 1 & 8,0000 & & & 8,00 & 8,00 \\
\hline & Cluster 2 & 6 & 7,1667 & 1,47196 & 0,60093 & 5,00 & 9,00 \\
\hline & Cluster 3 & 11 & 2,7273 & 1,10371 & 0,33278 & 1,00 & 5,00 \\
\hline & Total & 18 & 4,5000 & 2,57248 & 0,60634 & 1,00 & 9,00 \\
\hline \multirow{4}{*}{ 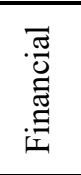 } & Cluster 1 & 1 & 4209850000,00 & & & $4,21 \mathrm{E}+009$ & $4,21 \mathrm{E}+009$ \\
\hline & Cluster 2 & 4 & 2050445375,00 & 2184993774,18 & 1092496887,09 & $3,97 \mathrm{E}+008$ & $5,26 \mathrm{E}+009$ \\
\hline & Cluster 3 & 10 & 646785293,42 & 396315693,57 & 125326026,415 & $1,01 \mathrm{E}+008$ & $1,29 \mathrm{E}+009$ \\
\hline & Total & 15 & 1258632295,61 & 1480765097,38 & 382331904,12 & $1,01 \mathrm{E}+008$ & $5,26 \mathrm{E}+009$ \\
\hline
\end{tabular}

Figure 2. Mean differences between groups
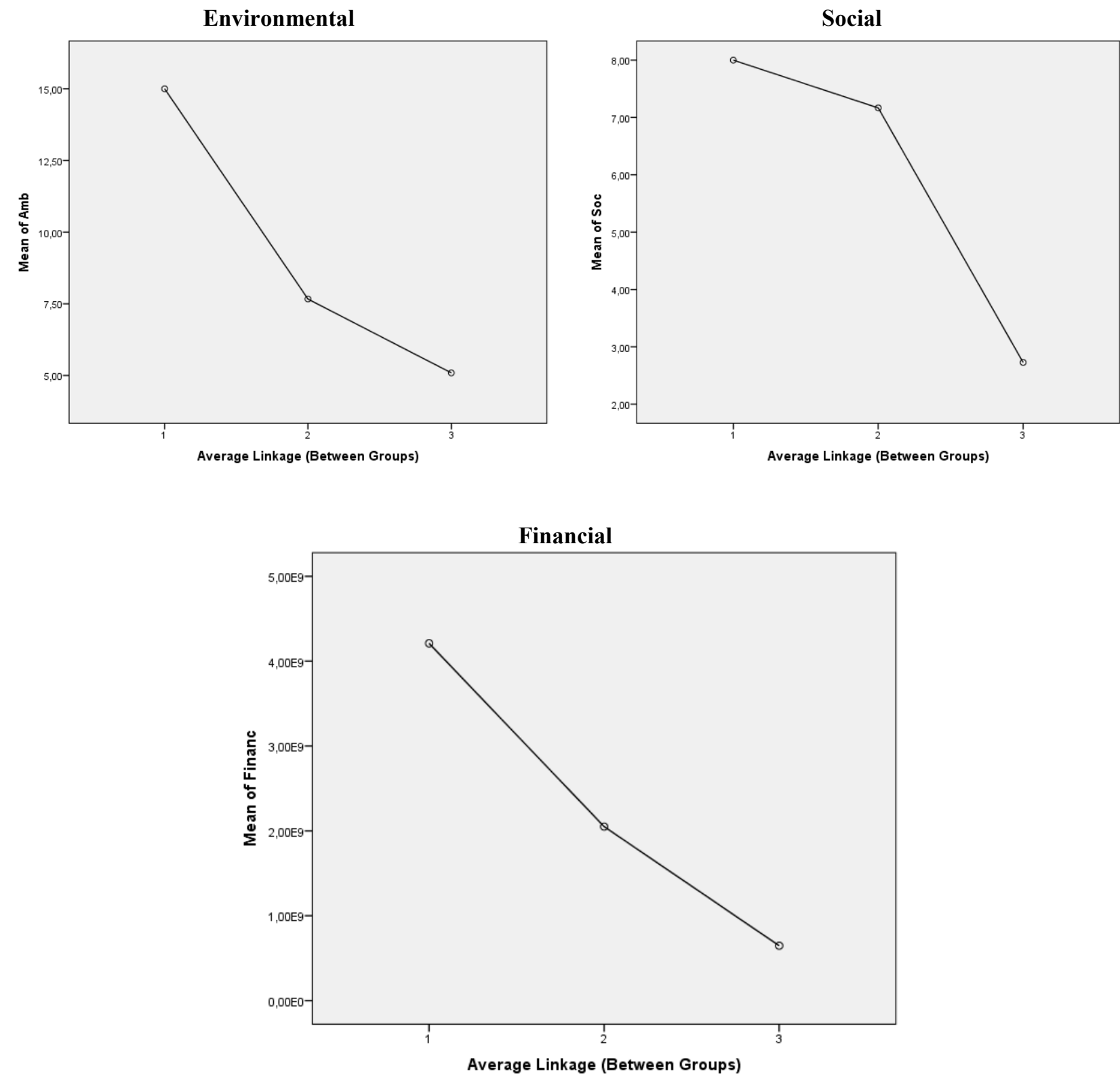

Revista de Gestão Social e Ambiental - RGSA, São Paulo, v. 13, n. 1, p. 57-75, jan./abr. 2019. 
It is observed through the descriptive statistics and through the graphs that there are differences of mean of environmental, social and financial performance among clusters. In other words, Cluster 1 shows environmental, social, and financial average performance higher than Cluster 2 which, in turn, presents environmental, social and financial average performance higher than Cluster 3. Thus, it can be inferred, in view of this result, an association among the variables of environmental, social and financial performance.

Cluster 1, formed only by the Group Louis Dreyfus Commodities, presents higher results in all variables, in other words, it was the group that reported the most environmental and social indicators and which presented the highest net revenue. Cluster 2, formed by six companies, presented average performance at an intermediate level in the three variables and Cluster 3 presented an average performance lower than the other clusters in the three variables. Thereby, it is observed that the higher the environmental and social performance, the higher the average revenue found which may suggest an association among these variables. It is worth emphasizing that this results work in an exploratory manner, we cannot state about a relationship or causality. In addition, the association may be related to the company's different characteristics, such as its size.

\section{DISCUSSION}

Regarding questions such as, what companies are reporting? And are social and environmental disclosure linked to economic performance or other factors? (Haniffa \& Cooke, 2005). The results show that the groups of companies still have a long way to go regarding the disclosure of environmental and social information. Some indicators with higher lives of disclosure are usually related to actions the companies have to take for reasons other than environmental or social awareness. Such as EN13 - Habitats protected or restored, reported by 14 groups. In Brazil, we have some laws regarding the protection of some part of farmland, so law, not a choice from the company, binds this practice.

Regarding the actions, such as "It generates electricity for own use", this practice could be simply a financial decision, to reduce the amount of electricity bough by the mill. However, clean energy production also minimize some externalities cause by the mills, what is consistent with the need to attend pressures related to the impact of their activities, according to Patten (1991). Thus, these results are consistent with the arguments of Buhr and Freedman (2001) regarding the relationship between economic, social and environmental aspects. This practices also have environmental impact, since they consist in reuse of by-products within the own chain, reducing environmental externalities (Pacheco \& Hoff, 2013).

The most common practices disclosed, such as (1) Reduce or eliminate the burning of sugarcane and CO2 emissions; (2) Preservation or restoration of Permanent Preservation Areas (PPAs) and RPPN (Private Reserve of Natural Heritage) or seedlings cultivation; and (3) Electricity power generation for its own use. All of the fit, in some way, in the first criteria from the CDM, the, contribution to local environmental sustainability (Brazil, 2014). These practices also contribute to other goals of CDM, such as quantifiable emissions reductions (Silveira, 2005), long-term benefits, emissions reductions of greenhouse gases or the increase in the $\mathrm{CO} 2$ removal from the atmosphere (Frondizi, 2009).

The very restrict amount of information disclosure is also expected from the smaller groups of mills, since the complete use of GRI reporting is still restricted mostly to larger companies from some industries (Brown et al., 2009). This evidence is associated with the firm maturity level. Some firm has higher level in the quality and extension of the disclosure, which can mean a higher level of maturity of social and environmental disclosure (Jenkins \& Yakovleva, 2006).

The results show that companies with better disclosure have, possibly, superior financial results. The positive association between disclosure and financial performance is corroborated by Chen et al (2015), Qiu et al. (2016), Platonova et al. (2018) and Oyewumi et al. (2018). This study does not analyze causality, but in an exploratory way it presents evidences that this relation can 
occur in companies with a greater level of disclosure. However, much still needs to be discussed about the quality of disclosure and its relation to business practice. In Brazil, companies with a high level of socio-environmental disclosure are directly involved in major environmental and social tragedies, as well as corruption scandals. This shows that it is relevant to analyze disclosure and its social, environmental and economic impacts, seeking to highlight the importance of reporting, but mainly, to raise sustainability practices.

\section{CONCLUSIONS}

This research had as main objective to identify the sustainability strategies of the Brazilian sugar and ethanol mills industry that participate in the Clean Development Mechanism (CDM).

Concerning the first specific objective, to measure the results of the mill's practices regarding social and environmental dimensions, we identified the main indicators reported with respect to environmental and social dimensions. About the environmental dimension, the most reported indicators by the mills refer to the organizations' initiatives and strategies for environment protection and preservation. On the social dimension, the most reported indicators refer to programs related to human resources management.

As for the second specific objective, to identify the practices undertaken by the mills aiming at environmental preservation and protection, we surveyed the environmental preservation practices resulting in 25 distinct actions. The most commonly performed practices are related to the reduction of cane burning and $\mathrm{CO} 2$ emissions; preservation or restoration of the Permanent Preservation Areas (PPAs) and Private Reserve of the Natural Heritage (PRNH) or seedlings cultivation; and electricity generation. It is noteworthy that the reduction of $\mathrm{CO} 2$ emissions are related to the CDM targets.

As regards to the third objective, identify the relationship between sustainability practices and financial performance of these organizations, we found that in the clusters where companies presented a higher social and environmental performance, in other words, that reported more indicators in these dimensions, it was also observed a higher volume of net sales revenue. This result indicates an association between the socio-environmental performance and the financial performance, considering the research limitations.

This research presents some limitations. The sample size did not allow for the use of more robust statistical techniques. In addition, the disclosure of incomplete information impairs the measurement and the mills performance more difficult to compare. Another limitation is that the groups surveyed present different number of mills, which complicates the comparison of the performances in the researched sample. Additionally, the financial performance was verified on different data sources.

This study contributes by presenting a performance analysis in sustainability of mills groups that participate in the Clean Development Mechanism (CDM). Although the participation in the CDM may indicate the companies' concern with sustainability, there is still opportunity for greater disclosure of the mills sustainability performance, through the disclosure of more comprehensive reports for a more effective communication with stakeholders and effectively demonstrate the industry's contribution to the sustainable development of their business. This study also contributes to the analysis of a specific sector. The literature presents different results for the analysis of disclosure and performance in different contexts. Deepening the analysis of industries in different countries contributes to the understanding of the different levels of disclosure and aspects that can be improved in social, environmental and economic reporting.

\section{REFERENCES}

Azzone, G., Bertelè, U., \& Noci, G. (1997). At last we are creating environmental strategies which work. Long Range Planning, 30 (4), 478-571. 
Bardin, L. (2011). Análise de conteúdo. São Paulo: Edições 70.

Barros, A. R. Uma avaliação das políticas públicas para o setor sucroalcooleiro no Brasil. (1996). Revista Econômica do Nordeste, 27 (3), 321-362.

Brazil (1997). Protocolo de Quioto à Convenção sobre a Mudança do Clima: o Brasil e a Convenção - Quadro das Nações Unidas. Ministério da Ciência e Tecnologia. Available at: http://www.mct.gov.br/upd_blob/0012/12425.pdf/. Accessed on: August 10, 2015.

Brazil (2014). Entenda como funciona o Mecanismo de Desenvolvimento Limpo (MDL). Portal Brasil. Available at: http://www.brasil.gov.br/meio-ambiente/2014/05/entenda-como-funciona-omecanismo-de-desenvolvimento-limpo-mdl/. Accessed on: July, 15, 2015.

Brown, H. S., Jong, M. de, \& Levy, D. L. (2009). Building institutions based on information disclosure: lessons from GRI's sustainability reporting. Journal of Cleaner Production, 17, 571580.

Buhr, N., \& Freedman, M. (2001). Culture, institutional factors and differences in environmental disclosure between Canada and the United States. Critical Perspectives on Accounting, 12(3), 293322.

Cervo, A. L., \& Bervian, R. S. (1996). Metodologia científica. São Paulo: Pearson Prentice Hall.

Chen, L., Feldmann, A., \& Tang, O. (2015). The relationship between disclosures of corporate social performance and financial performance: Evidences from GRI reports in manufacturing industry. International Journal of Production Economics, 170, 445-456.

Cormier, D., \& Magnan, M. (2015). The economic relevance of environmental disclosure and its impact on corporate legitimacy: An empirical investigation. Business Strategy and the Environment, 24(6), 431-450.

Conab (2010). Perfil do setor do açúcar e do álcool no Brasil. Brasília: Companhia Nacional de Abastecimento. Avaiable at:

http://www.conab.gov.br/OlalaCMS/uploads/arquivos/11_02_11_16_43_41_cana_de_acucar_2008 -09..pdf. Accessed on: August, 10, 2015.

Elkington, J. (1994). Towards the suitable corporation: win-win-win business strategies for sustainable development. California Management Review, 36(2), 90-100.

Exame (2014). As melhores empresas do Brasil em 2014. Available at: http://exame.abril.com.br/negocios/melhores-e-maiores/2014/. Accessed on: August 10, 2015.

Friedman, M. (1970). The Social Responsibility of Business is to Increase Its Profits. The New York Times Magazine, 13, 1-7.

Frondizi, I. M. R. L. (Coord.). (2009). O mecanismo de desenvolvimento limpo: guia de orientação 2009. Rio de Janeiro: Imperial Novo Milênio. Available at: http://unctad.org/pt/docs/cdm2009_pt.pdf. Accessed on: March, 08, 2018.

Gallego, I. (2006). The use of economic, social and environmental indicators as a measure of sustainable development in Spain. Corporate Social Responsibility and Environmental Management, 13 (2), 78-97.

García-Sánchez, I. M., Rodríguez-Ariza, L., \& Frías-Aceituno, J. V. (2013). The cultural system and integrated reporting. International Business Review, 22(5), 828-838.

Gatti, L., \& Seele, P. (2014). Evidence for the prevalence of the sustainability concept in European corporate responsibility reporting. Sustainability Science, 9(1), 89-102. 
Sustainability practices and performance in the sugar and etanol industry

Germek, H. A., Patrocínio, A. B. do, Silva, F. C. da, Simon, E. J., \& Ripoli, T. C. C. (2013). Analysis decision about the sugarcane straw recovery for cogeneration in unity operation industry. Bioenergia em Revista: Diálogos, 3 (2), 9-17.

Global Reporting Initiative. (2015). Available at: https://www.globalreporting.org/Pages/default.aspx. Accessed on: August 10, 2015.

Haniffa, R. M., \& Cooke, T. E. (2005). The impact of culture and governance on corporate social reporting. Journal of Accounting and Public Policy, 24(5), 391-430.

Holanda, A. P., de Almada, S. R., De Luca, M. M. M., \& Gallon, A. V. (2011). O Desempenho Socioambiental Nas Empresas Do Setor Elétrico Brasileiro: Uma Questão Relevante Para O Desempenho Financeiro?. Revista de Gestão Social e Ambiental, 5(3), 53-72.

IPEA (2010). Petróleo: da crise aos carros flex. Desafios do Desenvolvimento, 7 (59), 72-73. Avaiable at: http://www.ipea.gov.br/desafios/index.php?option=com_content\&view= article\&id=2321: catid=28\&Itemid=23. Accessed on: March, 08, 2018.

Jenkins, H., \& Yakovleva, N. (2006). Corporate social responsibility in the mining industry: Exploring trends in social and environmental disclosure. Journal of Cleaner Production, 14(3-4), 271-284.

Lloyd, B., \& Subbarao, S. (2009). Development challenges under the Clean Development Mechanism (CDM): can renewable energy initiatives be put in place before peak oil? Energy Policy, 37 (1), 237-245.

Mathuva, D. M., \& Kiweu, J. M. (2016). Cooperative social and environmental disclosure and financial performance of savings and credit cooperatives in Kenya. Advances in Accounting, 35, 197-206.

Moneva, J. M., Archel, P., \& Correa, C. (2006). GRI and the camouflaging of corporate unsustainability. Accounting Forum, 30(2), 121-137.

Novacana. [2019]. As usinas de Açúcar e Etanol do Brasil. Available at: https://www.novacana.com/usinas_brasil. Accessed on: March, 10, 2019.

Norman, W., \& Macdonald, C. (2004). Getting to the bottom of "Triple Bottom Line". Business Ethics Quarterly, 14 (2), 243-262.

Nyko, D., Valente, M. S., Milanez, A. Y., Tanaka, A. K. R., \& Rodrigues, A. V. P. (2013). A evolução das tecnologias agrícolas do setor sucroenergético : estagnação passageira ou crise estrutural ? BNDES Setorial, 37, 399-442. Avaiable at:

http://www.bndes.gov.br/SiteBNDES/export/sites/default/bndes_pt/Galerias/Arquivos/conheciment o/bnset/set3710.pdf. Accessed on: July, 30, 2015.

Oyewumi, O. R., Ogunmeru, O. A., \& Oboh, C. S. (2018). Investment in corporate social responsibility, disclosure practices, and financial performance of banks in Nigeria. Future Business Journal, 4(2), 195-205.

Pacheco, J. M., \& Hoff, D. N. (2013). Fechamento de ciclo de matéria e energia no setor sucroalcooleiro. Sustentabilidade em Debate, 4 (2), 215-236.

Patten, D. M. (1991). Exposure, legitimacy, and social disclosure. Journal of Accounting and Public Policy, 10(4), 297-308.

Pippo, W. A., \& Luengo, C. A. (2013). Sugarcane energy use: accounting of feedstock energy considering current agro-industrial trends and their feasibility. International Journal of Energy and Environmental Engineering, 4(10), 1-13. 
Platonova, E., Asutay, M., Dixon, R., \& Mohammad, S. (2018). The impact of corporate social responsibility disclosure on financial performance: Evidence from the GCC Islamic banking sector. Journal of Business Ethics, 151(2), 451-471.

Qiu, Y., Shaukat, A., \& Tharyan, R. (2016). Environmental and social disclosures: Link with corporate financial performance. The British Accounting Review, 48(1), 102-116.

Roca, L. C., \& Searcy, C. (2012). An analysis of indicators disclosed in corporate sustainability reports. Journal of Cleaner Production, 20(1), 103-118.

Silveira, G. B., Alberton, L., \& Vicente, E. F. R. (2017). O estado da arte da asseguração dos relatórios de sustentabilidade: Um estudo das empresas do índice de sustentabilidade empresarial (ISE) 2016. Revista de Gestão Social e Ambiental, 11(2), 36-53.

Silveira, S. (2005). Promoting bioenergy through the clean development mechanism. Biomass and Bioenergy, 28(2), 107-117.

Stead, J. G., \& Stead, E. (2000). Eco-enterprise strategy: standing for sustainability. Journal of Business Ethics, 24(4), 313-329.

Székely, F., \& Knirsch, M. (2005). Responsible leadership and corporate social responsibility: Metrics for sustainable performance. European Management Journal, 23(6), 628-647.

Tannuri, G., \& Van Bellen, H. M. (2014). Indicadores de desempenho ambiental evidenciados nos relatórios de sustentabilidade: uma análise à luz de atributos de qualidade. Revista de Gestão Social e Ambiental, 8(1), 2-19.

Toppinen, A., Li, N., Tuppura, A., \& Xiong, Y. (2012). Corporate responsibility and strategic groups in the forest-based industry: exploratory analysis based on the Global Reporting Initiative (GRI) framework. Corporate Social Responsibility and Environmental Management, 19, 191-205.

Viviani, S., de Moura, G. D., Macêdo, F. F. R. R., \& da Silva, T. P. (2014). A Evidenciação Ambiental Voluntária E Os Indicadores De Desempenho Empresarial De Companhias Abertas Participantes Do Índice Carbono Eficiente (ICO2). Revista de Gestão Social e Ambiental, 8(2), 1835.

Waddock, S. A., Bodwell, C., \& Graves, S. B. (2002) Responsibility: the new business imperative. Academy of Management Review, 16(2), 132-148.

WCED (1987). Our Common Future (The Brundtland Report). World Commission on Environment and Development.

Will, M. (2008). Talking about the future within an SME?: corporate foresight and the potential contributions to sustainable development. Management of Environmental Quality: An International Journal, 19 (2), 234-242.

Data da submissão: 09/03/2018

Data de aceite: $12 / 12 / 2018$

Revista de Gestão Social e Ambiental - RGSA, São Paulo, v. 13, n. 1, p. 57-75, jan./abr. 2019. 